\title{
S. HERITIER, L. LASLAZ (coord.), Les parcs nationaux dans le monde
}

Paris : Ellipses, 2008

Jean-Pierre Husson

\section{OpenEdition}

Journals

Édition électronique

URL : http://journals.openedition.org/rge/1673

DOI : $10.4000 /$ rge. 1673

ISSN : 2108-6478

Éditeur

Association des géographes de l'Est

Édition imprimée

Date de publication : 1 septembre 2007

ISSN : 0035-3213

\section{Référence électronique}

Jean-Pierre Husson, «S. HERITIER, L. LASLAz (coord.), Les parcs nationaux dans le monde », Revue

Géographique de l'Est [En ligne], vol. 47 / 4 | 2007, mis en ligne le 01 septembre 2011, consulté le 23 septembre 2020. URL : http://journals.openedition.org/rge/1673 ; DOl : https://doi.org/10.4000/rge. 1673

Ce document a été généré automatiquement le 23 septembre 2020

Tous droits réservés 


\section{S. HERITIER, L. LASLAZ (coord.), Les parcs nationaux dans le monde}

Paris : Ellipses, 2008

Jean-Pierre Husson

\section{RÉFÉRENCE}

S. HERITIER, L. LASLAZ (coord.), Les parcs nationaux dans le monde, Paris : Ellipses, 2008 


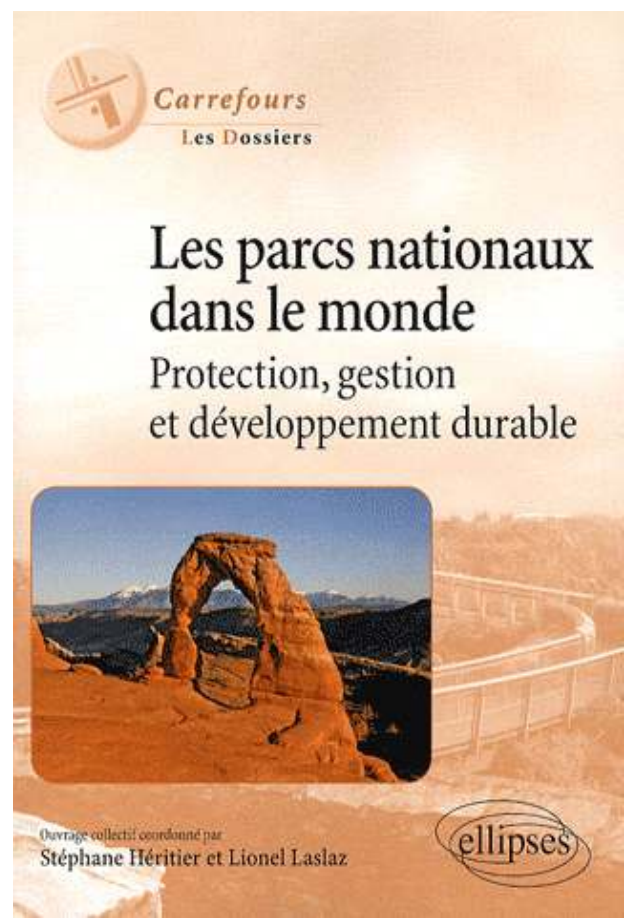

